\title{
Zeszyty PRASOZNAWCZE
}

Kraków 2017, T. 60, nr 4 (232), s. 743-759

10.4467/22996362PZ.17.043.8185

www.ejournals.eu/Zeszyty-Prasoznawcze/

\section{DZIENNIKARSTWO POWAŻNE W WYDANIU KSIĘDZA ADAMA BONIECKIEGO}

\author{
IWONA HOFMAN \\ Wydział Politologii \\ Uniwersytet Marii Curie-Skłodowskiej w Lublinie
}

\section{ABSTRACT \\ Serious journalism by Reverend Adam Boniecki}

As the Senior Editor of Tygodnik Powszechny, Reverend Adam Boniecki published two collections of comments, previously known from the publications in this weekly magazine in the years 2008-2014. These are: "Lepiej palić fajkę niż czarownice” (2011) and „Zakaz palenia” (2014). These comments meet the genre criteria, particularly in the explicit exposition of the author's views and readiness to hear other arguments and interpretation. They are also a very good example of serious journalism which I understand as a type of informational and opinionjournalistic writing covering issues important for the readers in the global and local context, authenticated with the author's authority and respecting communicational relationships. In the first part of the article, I discuss the course of the journalistic debate on journalistic standards, including opinions of editors-in-chief of the influential press. In the second part - I present an analysis of the contents of the selected texts of Rev. A. Boniecki. The comments published in Tygodnik Powszechny were mainly devoted to social issues where the teachings of the Church have a tremendous impact on human behaviour (e.g. sacraments for the divorced, abortion, in vitro), as well as to religious issues (ceremonies and celebrations connected with the liturgical year, political nature of sermons, decreasing number of vocations).

Keywords: opinion journalism, Tygodnik Powszechny, serious journalism, public opinion

Adres do korespondencji: Wydział Politologii UMCS; plac Litewski 3, 20-400 Lublin; iwona. hofman@umcs.lublin.pl 


\section{Wprowadzenie - dyskusja o standardach dziennikarstwa}

Ksiądz Adam Boniecki zainicjował w 2006 roku debatę na temat kryteriów profesjonalnego dziennikarstwa, pisząc w tekście „Przykazania medialne”:

Tylko reakcja środowiska dziennikarskiego, piętnowanie nieetycznych zachowań bez sankcji karnych, może stać na straży wartości, których żaden trybunał zapewnić nie zdoła. Pytam jednak niepewnie, czy w ogóle istnieją wśród nas powszechnie akceptowane autorytety, wyznaczające standardy? Czy potrafimy stworzyć instytucję, której charyzma byłaby dla nas - ludzi mediów - punktem odniesienia ważniejszym niż rankingi popularności? Być może nie. Ale zastanówmy się, co takie zaprzeczenie mówi o nas samych - ludziach władzy, już sam nie wiem: pierwszej czy czwartej (Boniecki 2006, s. 2).

Zainicjował w tym sensie - bo przecież wypowiedzi dziennikarzy na ten temat pojawiały się już od 2004 roku, co stanowiło swoiste przełamanie klimatu samozadowolenia w środowisku - że Jego refleksja spowodowała zebranie na łamach Tygodnika Powszechnego głosów dziennikarzy o różnych afiliacjach i przekonaniach światopoglądowych. W ankiecie wzięli udział: Kamil Durczok, Grzegorz Gauden, Igor Janke, Janina Jankowska, Katarzyna Kolenda-Zaleska, Ewa Milewicz, Monika Olejnik, Jacek Stawiński, Michał Viatteau-Kwiatkowski, Piotr Wojciechowski, Piotr Zaremba, Jacek Żakowski oraz Maciej Zaremba, i Joachim Trenkner omawiający status mediów i dziennikarzy w Szwecji, Francji i Niemczech (por. Ankieta Tygodnika Powszechnego 2006a, s. 8-9; Ankieta Tygodnika Powszechnego 2006b, s. 5). Każda opinia zasługuje na uwagę, można jednak uchwycić pewną dominantę, którą stanowi zbiór negatywnych praktyk. W świetle wypowiedzi dziennikarzy, są nimi: nonszalancja wobec faktów (obecnie, w skrajnej postaci funkcjonująca post-prawda), skłonność do uogólnień, personalizacja problemów, związki z polityką i politykami, gwiazdorzenie. Praktyki te miały uwarunkowania wynikające z braku stabilności zawodowej dziennikarzy, wymuszonej przez konkurencję pogoni za newsami (co doprowadziło do degradacji newsa jako gatunku dziennikarskiego), presji czasu i potrzeby bycia pierwszym w komunikacji o wydarzeniach, tabloidyzacji, celebrytyzacji, mediatyzacji życia publicznego. Najtrafniejszą diagnozę, jak dotąd niestety aktualną (a nawet mogłaby ona być jeszcze ostrzejsza), postawili wówczas, moim zdaniem, I. Janke i J. Stawiński. Janke napisał m.in.:

Coraz częściej zdarza się ,podkręcanie” tematu. Aby nadać materiałowi większą wyrazistość, autorzy nierzadko przekraczają cienką granicę między sugerowaniem a opisywaniem. Między thumaczeniem a nachalnym przekonywaniem czy nawet manipulacją [...]. Chorobą naszego środowiska jest stadne myślenie. Często mamy podobne sympatie polityczne. I niestety - zwłaszcza ostatnio - trudno nam to ukryć [...]. Najpoważniejszy problem to jednak głupota, brak profesjonalizmu i presji środowiska. Brak autorytetów. Brak poważnych instytucji (Ankieta Tygodnika Powszechnego 2006a, s. 9).

W wypowiedzi Stawińskiego czytamy zaś: 
Z całą świadomością stwierdzam, że największym zagrożeniem dla mediów jest niska jakość dziennikarstwa. To siła warsztatu dziennikarskiego decyduje o obecności danego medium na rynku, a nie ustawy i kodeksy, nawet najszlachetniejsze. Nie ostrość, ale bylejakość zagraża w dłuższej perspektywie mediom. Media pasywne to media dworskie, posłuszne. Rozwinięte demokracje nie mają mediów pasywnych, tylko media ostre, samodzielne, nieidące na polityczne kompromisy (Ankieta Tygodnika Powszechnego 2006b, s. 5).

Ankieta Tygodnika Powszechnego wywołała spory oddźwięk i nadal jest obecna w dyskursie na temat mediów ${ }^{1}$. Należy przypomnieć, że momenty autorefleksji dziennikarskiej pojawiały się wcześniej i z różnym natężeniem pojawiają się nadal, choć w bieżącej dekadzie XXI wieku wszystkich uczestników procesów komunikacji pochłaniają takie zagadnienia, jak: determinizm technologiczny, potencjał nowych mediów, komunikacja polityczna. W sekwencji artykułów poprzedzających ankietę warto wskazać przykładowo teksty: Adama Szostkiewicza „Wioska gapiów” (Niezbędnik inteligenta, Polityka 2004, nr 27/2458), Michała Karnowskiego, Amelii Łukasiak, Luizy Zalewskiej „Media kłamią czy się mylą” (Newsweek 2005, nr 22) oraz "Świat według naczelnych” (dodatek Przekroju 2005, nr 6/3111). Szostkiewicz zaakcentował utratę wiarygodności i komercjalizację mediów, cytując poglądy m.in. Pierre’a Bourdieu (media „kreują świat wyprany z debat ideologicznych, apolityczny, a zarazem pociagają wartościową prasę w odmęt komercji”), Michaela Ignatieffa (piętnującego media za podglądactwo i ,wyprzedaż zbanalizowanego horroru”), Noama Chomsky'ego i Paula Johnsona.

W sondażu Newsweeka poddano analizie wiarygodność mediów w kontekście błędów popełnianych przez dziennikarzy śledczych, chociaż to perspektywa zawężająca, konkluzje mają aspekt uniwersalny, np. na obniżanie się jakości mediów wpływają: „mordercza konkurencja” między dziennikarzami i redakcjami o prawo do newsa, ściganie przez media tradycyjne niedoścignionych, tj. Internetu, oraz zastapienie pracy poleganiem na ,przeciekach”.

W wymienionym dodatku ,Świat według naczelnych” znajduje się m.in. rozmowa z ks. A. Bonieckim, który zdefiniował media ,jako środek komunikacji społecznej, dzięki [któremu] ludzie mają możliwość uczestniczenia w życiu społeczeństwa, mający informować i pomagać zrozumieć rzeczywistość"; a ponadto podzielił się taką obserwacją:

1 Kontekstowo przytaczam fragment wypowiedzi J. Jankowskiej: „Najważniejszą wartością stał się marketingowy tytuł i szybkość ukazania się informacji. Nieważne są sposób jej pozyskania, jakość i konsekwencje publikacji. Można przełknąć ewidentne nieścisłości, półprawdy, insynuacje, przerywać rozmówcy ważną kwestię dla pytania z gotową tezą, dać lub nie dać sprostowania - jeśli przyniesie to rozgłos i podniesie nakład”; następnie E. Milewicz: „Praca dziennikarza jest jednak w tym sensie samotna, że to on decyduje, co widzi, a czego nie. To od jego głowy, ale przede wszystkim typu możliwości i zaciekawienia światem, zależy, co uzna za warte zbadania i w jaki sposób. Dziennikarz - nawet gdy kto inny mu wymyśli temat, podyktuje, z kim ma rozmawiać - ostatecznie zostaje z tematem sam”. M. Olejnik i G. Gauden zwracali uwagę na to „by dziennikarzami byli ludzie przyzwoici". 


\begin{abstract}
Media idą za pewnym wydarzeniem, wojną, trzęsieniem ziemi, piszą o tym, mówią, wręcz trąbią. Potem przychodzi następne wydarzenie i znowu wszyscy tam się przenoszą z kamerami i mikrofonami. A rzeczywistość tego poprzedniego wydarzenia z mediów kompletnie znika. A to jest niewierność rzeczywistości ludzkiej, której się dotknęło. Tragedia znika z pierwszych stron, ale przecież w rzeczywistości trwa nadal. Wadą jest poddawanie się modom, trendom sprawiającym, że materiały, które powinny się ukazać, są nieobecne, bo wypierają je właśnie tematy modne (Boniecki 2005, s. 16-17).
\end{abstract}

Oceniam tę wypowiedź jako fundamentalną dla ks. Bonieckiego jako publicysty.

Z 2005 roku pochodzi także głośny katalog dla dziennikarzy zestawiony przez Magdalenę Środę, zawierający następujące przykazania: „1) nie judź, 2) nie krzywdź, 3) mów - choć czasem - prawdę, 4) nie folguj ciekawości gawiedzi, 5) nie pijaruj, 6) nie bądź cynikiem, 7) myśl i skłaniaj do myślenia innych, 8) troszcz się o wolność, 9) troszcz się o równość, 10) staraj się lubić bliźnich (płci obojga) i zrób wszystko, by mieć szacunek dla samego siebie" (Środa 2005, s. 18-19). Przykazania te bardzo dobrze oddają zniesmaczenie opinii publicznej postępującą polityzacją mediów wyjaskrawianą przez zaangażowanie mediów w kampanie wyborcze, zwane już wtedy kampaniami permanentnymi.

W zbiorze tekstów opublikowanych po ankiecie Tygodnika Powszechnego można wyróżnić m.in. M. Środy „Dziennikarskie ciężkie grzechy” (Gazeta Wyborcza, 4 III 2008), Jacka Żakowskiego „Mea culpa” (Polityka 2008, nr 20(2654)), Macieja Wierzyńskiego „Czyja culpa” (Polityka 2008, nr 24(2658)), Klausa Bachmanna „Pożytki ze wścibskiej prasy” (Gazeta Wyborcza, 14-15 VI 2008), J. Żakowskiego „Reakcje redakcji” (Polityka 2009, nr 1 (2686)) ${ }^{2}$. Nadal zdecydowanie krytyczna M. Środa pisała o dziennikarzach-wykonawcach: „Świat traktuja jak plastyczny instrument, który daje się dostosować do potrzeb i żądań przełożonych" (Środa 2008, s. 21), oraz przestrzegała przed zacieraniem się funkcji mediów w domenach: informacyjnej, opiniotwórczej, perswazyjnej. Wypowiedzi Żakowskiego i Wierzyńskiego związane były z ostrym wystapieniem prezydenta Lecha Kaczyńskiego przeciwko nierzetelności mediów i przerostowi czwartej władzy w Polsce. Obaj publicyści przyznali, że „media popadają w syndrom nieuwagi" częściowo pod wpływem emocjonalnych mediów elektronicznych, są upartyjnione i żywią się sieczką plotek, insynuacji, „kłótni na żywo”. Obaj też odnieśli się do kwestii dziennikarstwa poważnego, które może kształtować społeczeństwo demokratyczne. Co ciekawe, Wierzyński podkreślał edukacyjną funkcję mediów i potrzebę zmiany nawyków publiczności medialnej, której aspiracje, by być lepiej poinformowana, rosną wraz z wykształceniem i poziomem życia.

2 Celowo wybrałam artykuły nieodległe w czasie od ankiety Tygodnika Powszechnego. Uważam bowiem, że po 2010 roku mamy do czynienia z inną koncepcją dziennikarstwa, opartą na prymacie komunikacji politycznej - dziennikarze stają się aktorami sceny politycznej, o czym pisała m.in. Bogusława Dobek-Ostrowska w książce „Polski system medialny na rozdrożu. Media w polityce. Polityka w mediach" (Wrocław 2011). 
Ironizujący Bachmann dał taki oto obraz mediów: „Media upraszczają, prowadzą kampanie, mobilizują czytelników, personalizują, moralizują i emocjonalizują. Muszą to robić, by czytelnikom wyjaśnić świat w pół godziny. [...] Najlepiej, jeśli wszystko da się sprowadzić do winy jednej osoby"3. Przeciwko tej formule świadczy ks. A. Boniecki jako publicysta.

\section{Dziennikarstwo jakościowe}

Mamy więc jedną wypowiedź dosłowną ks. A. Bonieckiego o mediach „niewiernych rzeczywistości ludzkiej" i jeden wniosek o metodzie dziennikarskiej ks. A. Bonieckiego wysnuty po lekturze Jego komentarzy, niejako „w kontrze” do obrazu trywialnych mediów ${ }^{4}$. Na tej podstawie można podjać próbę określenia cech prymarnych publicystyki ks. A. Bonieckiego lokalizowanej badawczo w warstwie dziennikarstwa poważnego. Inaczej mówiąc - można scharakteryzować tę publicystykę za pomocą wyznaczników dziennikarstwa poważnego.

Dziennikarstwo poważne rozumiem jako rodzaj pisarstwa informacyjnego i publicystycznego na tematy istotne dla odbiorcy w pespektywie globalnej lub lokalnej uwiarygodnionego autorytetem autora, pisarstwo niezależne, cechujące się poszanowaniem relacji komunikacyjnych ${ }^{5}$. W wielu analizach wyrażałam następujący pogląd:

Jakościowe dziennikarstwo realizuje wszystkie przypisane mediom funkcje, w tym edukacyjna. Jest zanurzone w instytucje i procesy dhugiego trwania, daje zatem odbiorcy możliwie wszechstronny i rozbudowany obraz rzeczywistości. Jakościowe dziennikarstwo zawiera przesłanki racjonalnych decyzji podejmowanych przez

3 K. Bauchman przywołuje termin „demokracja dramatu” belgijskiego socjologa Marca Elhardusa: „wszystko, co ważne, musi przybrać postać dramatu, z łzami, wściekłością, rozpisanymi rolami dla dobra i zła, tak abyśmy sami mogli przywdziać szaty sędziego”. Dalej pyta: „Choć, z drugiej strony, czy media publikowałyby takie historie, gdyby nikt nie chciał ich czytać? Czy w ogóle jest jakaś alternatywa?" (Bachmann 2008, s. 27).

$4 \mathrm{Na}$ temat profesjonalizmu dziennikarskiego i kondycji mediów pisałam m.in. w artykułach: Polityczny wymiar wojny z mediami (o media) u progu IV RP. W: W. Piątkowska-Stepaniak, B. Nierenberg (red.). Wojna w mediach. Opole 2007; Czy IV władza staje się pierwszą? W: T. Sasińska-Klas (red.). Media w wyborach. Kampanie wyborcze. Media w praktyce. Toruń 2007; Czy istnieje jeszcze informacja dziennikarska? W: L. Dyczewski (red.). Jaka informacja? Lublin-Warszawa 2009; Misyjność a prowincjonalizm mediów. Studia Medioznawcze 2010, nr 4(43); Współczesne standardy i wyzwania zawodowe w opiniach dziennikarzy. W: B. Kosmanowa (red.). Media dawne i współczesne, t. V. Poznań 2010; Między komercją a misją. Standardy zawodowe dziennikarzy a współczesny rynek mediów. W: I. Hofman. Studia nad dziennikarstwem. Lublin 2011. W artykułach tych przywoływałam stanowiska takich badaczy, jak: B. Dobek-Ostrowska, S. Gawroński, T. Goban-Klas, B. Hennessy, K. Jakubowicz, S. Michalczyk, M. Miller, S. Russ-Mohl, L. Szot.

5 Więcej na ten temat pisałam w następujących artykułach: Dziennikarstwo poważne a deprofesjonalizacja zawodu dziennikarza. Media dawne i wspótczesne 2011, nr 1, s. 109-122; Multigenetyczność dziennikarstwa w nauce i dydaktyce. Roczniki Nauk Społecznych KUL 2015, t. 7(43), nr 3, s. 115-124; Nowe Dziennikarstwo. Próba rekonstrukcji modelu. Atheneum 2016, nr 49, s. 68-77; The New Journalism: an Attempt at the Model Reconstruction. Polish Political Science Yearbook 2016, vol. 45, s. 391-398. 
uczestników aktów komunikacji, aktorów sceny publicznej. Wobec elit i rządzących pełni funkcję kontrolną, działa zatem jako hamulec czy dźwięk ostrzegawczy. Odbiorcy mediów, m.in. elektorat, zyskują dzięki dziennikarstwu jakościowemu orientację o problemach wpływających na standardy ich życia w każdej sferze. W sytuacji, gdy czynniki polityczne lub rynkowe ograniczają ten rodzaj przekazu, odbiorcy tworzą własne media, rodzi się dziennikarstwo obywatelskie bazujące na potencjale nowych mediów. [...] Dziennikarstwo jakościowe ma duże znaczenie zapobiegające zlaniu się domeny mediów i polityki (Hofman 2012, s. 99).

Wrócę jeszcze do kwestii odbicia rzeczywistych problemów społecznych w mediach: Ryszard Kapuściński przedstawił pogląd:

Media nie są zresztą wcale zainteresowane tym, by oddawać rzeczywistość - są zainteresowane wzajemnym współzawodnictwem. [...] Są poważne pisma, radiostacje, programy telewizyjne i $\mathrm{w}$ nich zachowało się odpowiedzialne dziennikarstwo w starym stylu. Ale jest to oczywiście mniejszość. Bo media w większości są dziś częścią dynamicznie rozwijającego się w skali planetarnej świata usług. Dlatego musimy pamiętać, że kim innym jest dziennikarz, a kim innym pracownik mediów (Kapuściński 2003, s. 121-122).

W innym miejscu doprecyzował: „Wraz z pojawieniem się telewizji i mediów elektronicznych mamy do czynienia $\mathrm{z}$ dwiema historiami: tą, która dzieje się rzeczywiście, i tą, która jest nam pokazywana. Przeważa obraz rzeczywistości medialnej, której przeciętny widz nie jest w stanie zweryfikować" (Kapuściński 2002, s. 13). Oba cytaty uzmysławiają wagę korelacji pomiędzy agendą medialną i publiczna, ale przede wszystkim uczulają na powstawanie medialnego obrazu świata (wyobrażonego). W głośnej książce Bernard Poulet, badając przyczyny zapaści rynku prasowego, zauważył, że wydawcy mediów opiniotwórczych, przyjmując błędnie zwycięstwo schematu komunikacji opartej na emocjonalnym, stadnym, falsyfikującym przekazie, zlekceważyli potrzeby wymagających odbiorców (Poulet 2011, s. 50-51, 119, 264-265). Odbiorcy ci poszukują rzetelnych informacji i miarodajnych interpretacji odnoszących się do świata rzeczywistego. Interesujące, że ten świat rzeczywisty posiada wyróżniki ciagłości i stałości. Przykładowo, Jerzy Stempowski w liście do Marii Dąbrowskiej, datowanym 17 grudnia 1962 roku, napisał: „Prasa żyje z novarum rerum studio, z pogoni za nowością. Z tej przyczyny wszystko, co świadczy o ciagłości i trwałości stosunków, uchodzi jej uwagi. O tym nikt nie pisze i nie mówi [...]. Tyle zjawisk tymczasem mówi o ciaggłości i stałości świata" (Dąbrowska, Stempowski 2010, s. 250). Podobnie sądził R. Kapuściński: ,środki masowego przekazu stworzyły wizję świata bardzo politycznego, chaotycznego i zupełnie oderwanego od dtugiego trwania, czyli od instytucji społecznych, postaw, mentalności i kłopotów zwykłych ludzi” (Kapuściński 2003, s. 20).

Wyznaczając pola analizy medioznawczej, przyjmuję zatem, że dziennikarstwo poważne posiada dwa atrybuty: wagę tematu i autorytet autora (lub tytułu medium). Edytoriale i komentarze ks. Adama Bonieckiego są bardzo dobrym materiałem eksploracji w tym zakresie. Ks. A. Boniecki związany jest z Tygodnikiem 
Powszechnym od 1964 roku, a w latach 1999-2011 był jego redaktorem naczelnym, zastępując swojego dziennikarskiego mentora i przyjaciela Jerzego Turowicza. Publikuje regularnie na pierwszej stronie tekstowej (nominalnie trzeciej), na okładkę krótkie teksty, klasyfikowane gatunkowo jako komentarz/editorial. Ich długość determinuje stałe miejsce eksponujące wypowiedź ks. A. Bonieckiego, teraz już Redaktora Seniora.

$\mathrm{Z}$ punktu widzenia medioznawcy, ale także odbiorcy mediów, uprzywilejowane i niezmienne miejsce druku stanowi jednoznaczny sygnał wartościujący komentarz. Istnieje bogata literatura przedmiotu zawierająca charakterystykę gatunku, w tym szczególnie przydatne prace Marii Wojtak, Andrzeja Kaliszewskiego, Kazimierza Wolnego-Zmorzyńskiego. Ze względu na fakt, że przeprowadzam analizę kryteriów dziennikarstwa poważnego, a nie cech gatunkowych, przywołuję jedynie wyjaśnienie zawarte w „Słowniku terminologii medialnej”. Komentarz zawiera interpretację rzeczywistości; w warstwie informacyjnej odnosi się do faktów współczesnych, ale nie jest to warunek konieczny (autorzy komentarzy często posługują się analogia, narracją historyczną lub adaptacją uwypuklająca przeszłość); w warstwie interpretacyjnej - do stanowiska autora (poprzedzonego polemiką, przywołaniem innych poglądów, przedstawieniem argumentacji różnych środowisk). Autorzy słownikowego hasła określili, iż „,elem zasadniczym komentarza jest wyrażanie stanowiska wobec zaistniałych faktów, ich analiza oraz rzeczowa argumentacja z przywoływaniem różnych punktów widzenia i polemizowaniem z nimi i ostatecznie przekonywanie autora do swoich racji”. Komentarz jest zatem, jak podała M. Wojtak, ,informacją zinterpretowaną", jakby informacją drugiego piętra (Wojtak 2004, s. 166). Cele perswazyjne komentarza stanowią swoistą przynętę dla polityków, ekspertów, piarowców przesadnie ufnych w swoje zdolności retoryczne. Komentarz w publicystyce jest poważnym tekstem, czasami w poetyce zbliżonym do felietonu, co otwiera ten gatunek wypowiedzi na swobodny styl. Tak rozumiany komentarz należy do domeny publicysty. Potencjał i atrakcyjność gatunku wynika ze struktury wypowiedzi: wyartykułowanie poglądów, przekonanie o ich słuszności, nakłonienie do ich przyjęcia. Przydatność komentarza w dziennikarstwie poważnym polega na uruchomieniu myślenia i wyobraźni czytelnika o tematach istotnych i stworzenie wspólnoty wartości.

Komentarze ks. A. Bonieckiego ukazały się w dwóch zbiorach: „Lepiej palić fajkę niż czarownice” (2011) i „Zakaz palenia” (2014) - na okładkach obu Ksiądz z nieodłączną fajką. Pierwszy zawiera teksty z lat 2008-2011, drugi 2011-2014. Pierwszy sprzedano w nakładzie 400 tysięcy egzemplarzy, co skłoniło Piotra Mucharskiego, obecnego naczelnego Tygodnika Powszechnego, do nieco sarkastycznej uwagi: „Od tego czasu niewiele się zmieniło, mądrość nie potaniała - przeciwnie" (Mucharski 2014, s. 5). Tylko dwa z komentarzy doty-

6 Autorami hasła „komentarz” są K. Wolny-Zmorzyński i A. Kaliszewski, zob. Pisarek 2006, s. 96 i 97. 
czą spraw osobistych Autora: „Nie poprzestać na tym, co zwykłe” (Tygodnik Powszechny 2011/47 - dalej TP), napisany po nałożeniu na ks. A. Bonieckiego przez prowincjała Zgromadzenia Księży Marianów zakazu wystąpień medialnych poza Tygodnikiem Powszechnym, oraz „Pięknie i pogodnie” (TP 2011/14) - stanowiący pożegnanie z funkcją redaktora naczelnego?

W słowach wstępnych do obu książek, P. Mucharski krótko scharakteryzował (przez uogólnienie) ich zawartość:

Głos w sprawach najważniejszych dla Polski i Kościoła, o sprawach najważniejszych w danym tygodniu dla naszego pisma, ale też głos o sprawach, które zwyczajnie zaprzątają głowę Redaktora Seniora. Można na tę książkę spojrzeć właśnie w ten sposób: jest to zapis myśli, które akurat nachodzą księdza Adama Bonieckiego. Jest to więc również zapis intymny. Zawsze odpowiedzialny, zwykle ważący słowa, czasem zabójczo ironiczny, przeważnie głęboko religijny. W każdym wydaniu jednak pozwalający sobie na ryzyko myślenia i dający do myślenia (Mucharski 2011, s. 5);

\section{kontynuując:}

Ksiądz Adam Boniecki pisze co tydzień... swój komentarz do najważniejszych wydarzeń, które Polaków dotyczą. Czyli niekoniecznie tych, którymi żyją media. Proponuje nam swój osobny trakt, wybrany według wartości, które wyznaje [...] edytoriale [...] uprzytomniają, jak bardzo potrzebny jest nam dzisiaj dystans połączony z zaangażowaniem, jak deficytową postawą jest zrównoważenie, którego źródłem jest zwyczajna mądrość (Mucharski 2014, s. 5).

Wydobyć należy i zapamiętać jako cechy immamentne dla pisarstwa ks. A. Bonieckiego słowa i określenia: sprawy najważniejsze, niekoniecznie medialne, odpowiedzialność, ważenie stów, osobny trakt wartości, dystans, zaangażowanie, zrównoważenie, madrość. Określają one predyspozycje komentarzy do dziennikarstwa poważnego 8 .

Komentarze ks. A. Bonieckiego, w przeważającej części, poświęcone są tematyce religijnej. To oczywiste, biorąc pod uwagę profil tygodnika i posługę Autora. Nawiązują do roku liturgicznego (Boże Narodzenie, Zmartwychwstanie, Zesłanie Ducha Świętego), obyczaju (Święto Zmarłych) i problemów Kościoła (mała

7 W tekście tym, ks. A. Boniecki napisał m.in. „Siłą [Tygodnika Powszechnego - przyp. I.H.] jest to, co nam pozostawił Jerzy Turowicz. A oprócz pokolenia następców, zostawił nam profil i charakter pisma [...]. Dzięki temu, choć czasy się zmieniaja, wciąż trwa środowisko Tygodnika Powszechnego: ludzie mówiący podobnym językiem, kultywujący te same wartości, toczący spory o sprawy, które są sporów naprawdę warte". Tekstowi towarzyszył dopisek P. Mucharskiego, nowego redaktora naczelnego, zatytułowany „Miejsce dla Bonieckiego” (Boniecki 2011, s. 128-129).

8 We Wstępie do „Zakazu palenia” ks. Adam Boniecki, przywołał nieco humorystycznie radę, jaką otrzymał od Andrzeja Grzegorczyka, daną po ogłoszeniu zakazu wystąpień publicznych. Brzmiała ona tak: „Ty też miałbyś korzystniejszą dla swojej roboty sytuację, gdybyś więcej wagi przykładał do uczenia swoich odbiorców właściwych postaw intelektualnych. Mam tu na myśli to, że często piszesz zbyt skrótowo i jakby licząc na inteligencję odbiorcy. Tymczasem odbiorca twój, nawet inteligentny i wykształcony, często ma tę swoją inteligencję nieco przyćmioną na skutek swojej postawy emocjonalnej i mówiąc do niego, należy najpierw wywołać w nim postawę pewnego obiektywizmu intelektualnego" (Boniecki 2014, s. 6). 
liczba powołań, pustoszejące kościoły, celibat, pedofilia, upolitycznienie kazań). Często dotyczą kwestii społecznych, w których stanowisko Kościoła ma decydujący wpływ na zachowania ludzi (sakramenty dla rozwiedzionych, aborcja, in vitro, alkoholizm, narkomania). Głos ks. A. Bonieckiego wolny jest od moralizatorstwa, bycia wątpiącym - przez co silny, bo wiarygodny ewangeliczną postawą wobec bliźnich.

Mają świetnie skomponowane tytuły: dające do myślenia („Nasza biedna agresja obronna”, „Wielkie ryzyko Pana Boga”, „Najpierw porozmawiaj ze sobą”, „Mądrość ludzi starych”, „Wiara jako wybór”, „Nie musimy kopać przepaści”, „Żeby nie zgubił się Jezus”), dosłowne („Numer papieski”, „Vademecum śmiertelnika”, „,Kilka myśli o radości”, „Nie czytajcie Grossa, jeśli...”, „Wielkość kardynała Martiniego”, „Na 11 listopada”, „Gender w Dolinie Kościeliskiej”), krotochwilne („Gazeta ciekawa jak list pasterski”, „Gdzie jest przód?”, „Obciach: moja lista”, „Mniejsza połowa”, „Szatan, w którego nie wierzę”, „Przecież nie yerba mate”, „Kochaj i rób, co chcesz”, „Alergikom na uspokojenie”). Bohaterami komentarzy bywają osoby publiczne, szczególnie papieże: Benedykt XVI i Franciszek - w wymiarze ich oddziaływania i stylu komunikacji (w szerokim rozumieniu języka nauczania i komunikacji z wiernymi). Bardzo ważne są w strukturze komentarzy ostatnie akapity - puenty. Nie mniej ważne - konteksty i - jednak - aktualność.

\section{Analizy}

Komentarz „Gazeta ciekawa jak list pasterski” (TP 2008/46) zawiera polemikę ze stanowiskiem abp. Józefa Michalika, przewodniczącego Konferencji Episkopatu Polski, który pominął Tygodnik Powszechny w swoim wykazie mediów katolickich.

Przyszłość katolickich mediów w Polsce widzi Przewodniczqcy Konferencji w rozwoju Niedzieli, Radia Maryja i Telewizji Trwam. Być może ma rację, czytelnicy o tym zdecyduja. Ale zdecyduja w ten sposób nie tylko o przyszłości katolickich mediów, ale całego Kościoła w Polsce. Co zaś się tyczy Tygodnika, kolejny numer potwierdza najgorsze przewidywania Księdza Arcybiskupa: rozpoczynamy druk cotygodniowych komentarzy do żydowskich czytań biblijnych w synagodze. Czy jest to do pomyślenia w czasopiśmie katolickim?! (Boniecki 2011, s. 22)

podsumował ks. A. Boniecki. „Dezyderata” (TP 2008/48) stanowi wypowiedź na temat lustracji, której uznanie za pożyteczną staje się deklaracją polityczną. W komentarzu Autor odnosi się do zapowiedzi ks. Tadeusza Isakowicza-Zaleskiego oddania Medalu Świętego Jerzego w proteście przeciwko przedrukowaniu przez Gazete Wyborczq innego komentarza ks. A. Bonieckiego, podającego w wątpliwość informacje o zarejestrowaniu przez SB ks. Józefa Życińskiego jako tajnego współpracownika. „Ani miejscem, ani językiem, ani strojem” (TP 2009/26) o nacjonalizmie i nowoczesnym patriotyzmie ma następujące zakończenie: 
Unia Europejska, nawet bez invocatio Dei, jest w zamyśle bliska chrześcijańskiemu rozumieniu patriotyzmu i uniwersalnego otwarcia na innych. Teraz nowego patriotyzmu musimy się nauczyć. Mniej w nim miejsca na szable, którymi się odbiera „,co nam obca przemoc wzięła", więcej na wspólne dobro narodów budowane w sposób pokojowy (Boniecki 2011, s. 46).

Komentarz „Strefa ludzkich sumień” (TP 2009/28) wybrzmiał podczas toczącej się wówczas debaty o in vitro. Ks. A. Boniecki napisał o ewolucji nauczania Kościoła wynikającej z konieczności dostosowania nauki do postępów technologii. Zastrzegając, iż trudno oczekiwać zmian $\mathrm{w}$ kwestii in vitro i poszanowania ludzkiego życia, zakończył w sposób niezwykle wyważony: Strefa ludzkich sumień zawsze musi pozostać otoczona szacunkiem. Zawsze za konkretnq decyzja będzie stał konkretny, wolny człowiek, bez względu na zakres określonej przez prawo swobody działania. Rzecz w tym, żeby wybierajac, wiedziat, co wybiera. Nie sqdźmy nikogo, bo sędziq sumień jest Bóg (Boniecki 2011, s. 50). „Rozwiedzeni” (TP 2009/31), zgodnie z tytułem, w kontekście adhortacji „Familiaris consortio” Jana Pawła II. „Pogarda i zgorszenie” (TP 2009/33) ma za temat poszanowanie uczuć i przekonań religijnych. „Najpierw porozmawiaj ze sobą” (TP 2009/34) - uzależnienie alkoholowe. „Moi Wszyscy Święci” (TP 2009/44) był zamieszczony w numerze listopadowym i wzruszał serdeczną pamięcią o ks. Bronisławie Bozowskim, Hannie Chrzanowskiej, ks. Władysławie Vanaksie i innych przyjaciołach Boga, których spotkat. „Przebudzenie” (TP 2010/16) - napisany tuż po katastrofie smoleńskiej, zbudowany z akapitów poświęconych kruchości życia, wspólnocie i dobru, które objawiło się podczas przeżywania tragicznych momentów, zawierał i takie stwierdzenie: Śmierć nie kanonizuje żadnej politycznej wizji ani strategii (Boniecki 2011, s. 77). Tekst o beatyfikacji ks. Jerzego Popiełuszki - „Wino z błogosławionym” (TP 2010/24) - kończy zdanie pełne niepokoju i profetyczne: Bardzo źle by się stało, gdyby ktoś chciał go teraz zawtaszczyć i używać do zwalczania myślacych inaczej (Boniecki 2011, s. 86). „Mądrość ludzi starych" (TP 2010/27), na czym polega? Wtedy wiele spraw powraca na wtaściwe miejsce, proporcje ważności odzyskuja swoja miarę (Boniecki 2011, s. 90).

Komentarz „Wołga, Wołga” (TP 2010/40) właściwie powinien był cyklicznie wznawiany wobec problemów aspiracji politycznych hierarchów Kościoła, sporów o utracone mienie kościelne i wysokość rekompensat. Został napisany po aresztowaniu Marka P., pełnomocnika parafii i zakonów przed Kościelną Komisją Majątkową, a w czasach PRL funkcjonariusza milicji i SB. Ks. A. Boniecki patrzy na sprawę szerzej:

głównym źródłem irytacji jest bezsilność. Kościót w wielu sprawach uparcie idzie pod prąd nowoczesności. Niezmiennie jest przeciwnikiem aborcji, uparcie nie godzi się na zrównanie gejowskich zwiqzków z matżeństwem, uparcie (i powie ktoś: anachronicznie) broni nierozerwalności matżeństwa oraz wstrzemięźliwości seksualnej przed zawarciem malżeństwa, no i jest przeciwny zapłodnieniu in vitro. Jest on zbyt starq instytucja, by żywić złudzenia co do powszechnej skuteczności swych wymagań. Jednak trwa przy swoich przekonaniach, wciaż szukajac, z lepszym czy gorszym skutkiem, języka, którym o słuszności swojej wizji człowieka trafi także do 
ludzi niewierzacych. Odebranie Kościołowi prawa do wypowiadania swoich przekonań jest w państwie demokratycznym dość trudne - tatwiej go zdyskredytować. Nie uważam fali irytacji antykościelnej za nieszczęście. Wprost przeciwnie. Ona zmusza nas do uświadomienia sobie popetnionych błędów i grzechów, nawrócenia $i$ naprawienia krzywd. Punktem odniesienia $w$ tym rachunku sumienia musi być Ewangelia, a nie żaden inny dokument, choćby nawet byt nim konkordat (Boniecki 2011, s. 102).

W tekście „Ukryte światło konsumpcji” (TP 2010/51) ks. A. Boniecki racjonalizował opinie o wyłącznie konsumpcyjnym wymiarze Świąt Bożego Narodzenia, dostrzegając w podarkach i wspólnej kolacji wigilijnej np. z bezdomnymi znak radości i miłości. „Nic w historii nie jest biało-czarne” (TP 2011/9) to najkrótsza recenzja książki Romana Graczyka „Cena przetrwania”, omawiającej inwigilację środowiska Tygodnika Powszechnego i Znaku w PRL. W komentarzu „Osobno i razem” (TP 2011/16) przedstawiał przykre i żenujące procesy instrumentalizacji politycznych katastrofy smoleńskiej, aż - w ciągu zaledwie roku - podzieliła Polaków. Mobilizację polityczną wokół katastrofy o. Ludwik Wiśniewski nazwał na łamach Tygodnika Powszechnego - „rokiem żałoby”. Odczytuję kilka zdań podsumowujących jako próbę uwznioślenia katastrofy w dyskursie publicznym:

Mamy przed sobq beatyfikację Jana Pawła II. [...] Dywagacje typu: „, co by powiedziat, gdyby żyt?" traca natomiast hipokryzjq. Przecież niestrudzenie wzywat nas do solidarnej jedności. Już nie pamiętamy: , Solidarność - to znaczy: jeden i drugi, a skoro brzemię, to brzemię niesione razem, we wspólnocie. A więc nigdy: jeden przeciw drugiemu" (Gdańsk-Zaspa, 12 czerwca 1987 r.). A może nie jest tak źle? Może w społecznej pamięci ożywionej perspektywa tak wyczekiwanej beatyfikacji tamte słowa okaża się silniejsze od wezwań do nienawistnej walki? Może Duch Święty znów zstapi i znów odnowi oblicze ziemi, tej ziemi? (Boniecki 2011, s. 132).

Komentarz „Sam na sam ze Świętym” (TP 2011/18) zawiera relację z rzymskich uroczystości beatyfikacji Jana Pawła II. „Mniejsza połowa” (TP 2011/29) dotyczy miejsca kobiet w Kościele i społeczeństwie. „Biskup listy pisze” (TP 2011/37) - treści ogłoszonego przez Episkopat listu „Wszyscy zacznijmy wychowywać", który wzbudził kontrowersje jako bezwarunkowa pochwała dawnych metod wychowawczych (w drugim planie ks. A. Boniecki analizuje prawdopodobne powody spadającego w Polsce stopnia zaufania do Kościoła).

W komentarzu „Szatan, w którego nie wierzę” (TP 2011/40) ks. A. Boniecki odpowiadał na list bp. Wiesława Meringa w sprawie swojej wypowiedzi na temat obecności w telewizji publicznej Adama „Nergala” Darskiego, przypominając słowa Jezusa o istnieniu Szatana, świadectwo o. Jana Kłoczowskiego, książkę André Frossarda „36 dowodów na istnienie diabła” i konkludując:

Pewnie, Diabet bywa raz uprzejmy, innym razem agresywny. Ale żeby się pojawiat $w$ diabolicznym dekorze, dymie i przy akompaniamencie metalu? Nie słyszałem. Często stuchajac opowieści o szatanie i satanistach, odnoszę wrażenie, że jeśli tam jest jakiś szatan, to nie ten, w którego istnienie wierzę (Boniecki 2011, s. 162). 
Kontynuacja - „Zakaz palenia” (trwalszy niż nakaz, dlatego zaakceptowany w tytule). „Nie ma pytań pilniejszych” (TP 2012/7) - jeden z nielicznych przykładów komentarzy dedykowanych osobie: pożegnanie Wisławy Szymborskiej, która tuż przed śmiercią ofiarowała Tygodnikowi Powszechnemu wiersz-przestrogę („Byśmy byli z tego świata i nie lękali się żadnej napastliwej prawdy”). Komentarz mający za temat katastrofę kolejową pod Szczekocinami nosi tytuł „Noc bezradnej solidarności”; media najbliżej ratowników, okoliczni mieszkańcy z najpotrzebniejszymi kocami i herbatą, kipiący doniesieniami Internet, pyta Boga - czy steruje pociaggami, dlaczego giną ludzie; i wyciszające zakończenie:

Memento mori, pamiętaj, że umrzesz. Nagle odkrywamy na nowo stare powiedzenie, nagle odkrywamy, że wciqż się ocieramy o niespodziewanq śmierć. Naszq czy naszych bliskich. Że nasz ziemski czas jest ograniczony. Odkrywamy, żeby znów zapomnieć (Boniecki 2014, s. 28).

$\mathrm{W}$ drugą rocznicę katastrofy smoleńskiej ks. A. Boniecki opublikował komentarz „Pana Havla anatomia nienawiści” (TP 2012/17), w którym odwołał się do przemówienia Václava Havla wygłoszonego w 1990 roku w Oslo; tekst komentarza składa się z przypomnień konstatacji Havla:

Ludzie nienawiści kieruja się stałym, uporczywym i przesadnym poczuciem krzywdy. Chcieliby być powszechnie szanowani, poważani i kochani, a tymczasem - jak im się wydaje - jest wręcz przeciwnie, sq lekceważeni. Podświadomie uważajq siebie za jedynych posiadaczy całej prawdy, zastugujacych na szacunek i ślepe postuszeństwo. [...] Człowiek nienawidzacy nigdy nie potrafi $w$ sobie dostrzec przyczyn swego niepowodzenia. Nie wie, że przecenia swoje możliwości. Abstrakcyjnego winowajce własnej klęski chętnie personifikuje, wynajdujac konkretnego winnego. [...] Ludzie nienawidzacy to ludzie z kompleksem niedoceniania własnej wartości przez nieprzychylny los. [...] Zbiorowa nienawiść rodzi się niezauważalnie [...] jest groźna. Historia uczy, że zaczadzeni nienawiścia ludzie sa zdolni do najgorszych czynów i że zbiorowa nienawiść przyciaga ludzi do niej indywidualnie zdolnych (Boniecki 2014, s. 43, 44).

To przypomnienie słów Havla oddawało intuicyjne przeczucie nastrojów w Polsce.

„Wiara jako wybór” (TP 2012/18-19) - o innej religijności Polaków, zwanej „religijnością pielgrzyma” lub „religijnością konwertyty”, opartej na subiektywnie wybranych treściach wiary. „Pro-life: czasem się udaje” (TP 2012/25) - o ruchu i społecznych kampaniach, w których język potępienia i poniżenia został zastapiony czytelną informacją i pomocą dla kobiet. „Nie musimy kopać przepaści” (TP 2012/26) - o podziale na "lepsze" i „gorsze” mediów katolickich: dlaczego Tygodnik Powszechny nie jest rozprowadzany przez parafie? Odpowiedź: bo wyskakuje z pytaniami tam, gdzie zwykle pytań się nie stawia, podejmuje debaty w sprawach, które się wydaja raz na zawsze ustalone (Boniecki 2014, s. 53).

„Do moich internetowych nieprzyjaciół” (TP 2012/32) - Dlaczego mnie tak nie znosicie? O co naprawdę Wam chodzi? Przecież mnie nie znacie i nawet nie czytacie tego, co piszę (Boniecki 2014, s. 63). Na łamach pisma ukazał się wów- 
czas apel do ministra sprawiedliwości i prokuratora generalnego o podjęcie działań przeciwko mowie nienawiści. „Wyzysk” (TP 2012/36) - umowy „,́́mieciowe” jako problem społeczny. „Ten sam, choć nie taki sam” (TP 2012/40) zawierający programowe założenia Jerzego Turowicza, w tym - pozycjonujące współcześnie pismo na rynku mediów: katolickość, personalizm, współodpowiedzialność za państwo, dialog, krytyczny stosunek do rzeczywistości (polityki, kultury, funkcjonowania Kościoła jako instytucji). Przykład dialogu - w komentarzu „Rozmowa niemożliwa/możliwa" (TP 2012/45) pomiędzy ks. Andrzejem Dragułą i Marią Peszek. „Wspólnota” (TP 2012/46) - z okazji 11 listopada: Nie wzywajmy imienia ojczyzny bez umiaru, nie licytujmy się patriotyzmem. Naszq dume testujmy codzienna gotowościq do poświęceń na rzecz wspótobywateli (Boniecki 2014, s. 87).

„Mały pęcherzyk” (TP 2014/47) to komentarz-odpowiedź na felieton Rafała Ziemkiewicza wydrukowany na łamach Gazety Polskiej w związku z fotografią ks. Bonieckiego i Nergala, a w następstwie - wymianą listów między Haliną Bortnowską i Magdaleną Środa. „Na drzewo z tymi, co się sprzeciwili” (TP 2013/5) - w związku z sejmową debatą o związkach partnerskich.

Ważny tekst „Sede Vacante” (TP 2013/7) o decyzji ustąpienia z urzędu papieża Benedykta XVI - to gest wielkiej odwagi, naruszenie odwiecznej, mimo nielicznych wyjatków, kościelnej praktyki (Boniecki 2014, s. 105).

„Ojciec Ludwik” (TP 2013/9) - komentarz solidaryzujący się ze stanowiskiem o. Ludwika Wiśniewskiego, który napisał m.in. „sprzeciwiam się manipulowaniu żarliwością religijną", gdy biskupi zaangażowali się w akcję mającą doprowadzić do przyznania TV Trwam miejsca na multipleksie.

W komentarzu „Będziemy mieli dwóch papieży” (TP 2013/10) Autor wraca do odejścia Benedykta XVI, który w ostatniej katechezie wytłumaczył, że ustąpienie z posługi jest także „,sposobem jej sprawowania”. „,Franciszek, biskup Rzymu" (TP 2013/12) - komentarz po wyborze następnego papieża, z serdecznym wyznaniem:

Moje serce podbit pierwszym papieskim słowem, skierowanym do Miasta i Świata. Ileż trzeba wewnętrznej wolności, spontanicznej życzliwości i wyczucia chwili, żeby zaraz po wyborze na papieża wyjść na balkon i do wielotysięcznych tlumów powiedzieć całkiem po prostu, tak jak się mówi, wchodzq̨ do przyjaciót: ,dobry wieczór" (Boniecki 2014, s. 117).

Komentarzem „Piękna nasza Polska cała?” (TP 2013/17-18) ks. A. Boniecki włączył się w reporterskie zadanie Przemysława Wilczyńskiego i Marcina Żyły, którzy wędrując po kraju, prosili ludzi o rozwinięcie zdania „Polska jest fajna, bo...". Wyliczenie powodów, m.in. budowa dróg, spotkania z czytelnikiem pisma, działalność Polskiej Akcji Humanitarnej i Muzeum Historii Żydów Polskich, Autor zakończył zdaniem: A najbardziej cieszq mnie ci, którzy potrafiq się z nich cieszyć (Boniecki 2014, s. 127). „Wielki Plusk” (TP 2013/23) to komiczny komentarz z wykorzystaniem wiersza Juliana Tuwima, ilustrującym zabiegi 
reklamowe i marketingowe, aby dowartościować każdą rzecz jako „naj”. W komentarzu „Opowieść straszna o moich prapradziadkach” (TP 2013/26) Redaktor Senior zrecenzował tetralogię Jarosława Marka Rymkiewicza („Wieszanie”, „Kinderszenen”, „Samuel Zborowski” i „Reytan. Upadek Polski”), która stała się dla wielu Polaków wyznacznikiem patriotycznej historiografii. Sprawozdanie z festiwalu Przystanek Woodstock znajdziemy w tekście „Kochaj i rób, co chcesz" (TP 2013/32) - referując thumne spotkanie z młodzieżą na temat wiary, ks. A. Boniecki spuentował: Powiedziatem wam o mojej wierze, o Bogu. Teraz wy, młodzi przyjaciele. Wasz wybór, wasza decyzja, wasza wolność. „Róbta, co chceta" - powiedziatem, wiedzqc, że za to jeszcze oberwę (Boniecki 2014, s. 152). Komentarz „Była chlebem” (TP 2013/37) był poświęcony Simone Weil. „Na 11 listopada" (TP 2013/45) ks. A. Boniecki napisał (w Warszawie, w Święto Niepodległości, były znowu burdy i zamieszki):

Obchody święta narodowego prowokuja do pytań o to, co nas, jako naród łaczy. Nie zagrożenie granic, bo takiego zagrożenia nie ma. Nie Kościót, ten - jak się zdaje - czasem ludzi, nawet wierzqcych, potrafi podzielić. Nie Jasna Góra (,,Tutaj zawsze byliśmy wolni" - JPII) - kiedyś wspólny cel pielgrzymek Polaków ze wszystkich zaborów, dziś zawłaszczona przez „prawdziwych Polaków”. Także nie historia, zwłaszcza najnowsza, używana i nadużywana $w$ politycznych walkach. Dobro wspólne Ojczyzny? Wiemy, jakie reakcje budzi perspektywa jakiegokolwiek wyrzeczenia w imię wspólnego dobra. Może jeszcze łaczy nas biedny polski język - spłaszczany, zaśmiecany $i$ pozbawiany regionalnych cech przez wszechobecne media. A jednak jest coś, co dziś nas integruje jako naród: nasze któtnie. Ten, kto nie należy do naszego narodu, nigdy nie zrozumie zaciekłości i podziałów na tle Radia Maryja, katastrofy smoleńskiej, sporów o lustrację, ksiązki Jana Grossa, o prezydenta Warszawy itd. Każdy zrozumie, że to kwestie sporne, ale pasji, z jakq drażymy na tle tych kwestii między sobq podziały, nikt z zewnatrz nie pojmie. Jako naród trwamy $w$ nieustajacym zwarciu, w śmiertelnym uścisku i sporze. To nas jako polski naród - niewatpliwie łączy (Boniecki 2014, s. 171-172).

I dalej:

Polsko, $w$ dniu Twojego święta życzę Ci, byś była domem wszystkich. By nikt nie czut się wypchnięty za drzwi, poniżany. Życzę, choć wiem, ̇̇e życzenia nie maja mocy sprawczej. Moc sprawczq ma to, jacy będa Polacy (Boniecki 2014, s. 172).

Komentarze „Franciszek i rozwiedzeni” (TP 2013/46) oraz „Gender w Dolinie Kościeliskiej” (TP 2013/50) dotyczą kolejnych istotnych kwestii społecznych, z którymi zmagał się Kościół. „Bóg nie chce śmierci grzesznika, ale by się nawrócił i żył" (TP 2014/3) stanowi wypowiedź w związku z dyskusją o książce Doroty Kani, Jerzego Targalskiego i Macieja Marosza „Resortowe dzieci. Media”. W komentarzu tym ks. A. Boniecki stwierdził m.in.

Jest w niej ekstrakt tego, co w postaci bardziej rozrzedzonej występuje dziś w myśleniu wielu u nas ludzi. Jest więc żal, że przemiany w Polsce dokonaty się bez mściwego niszczenia pokonanych przeciwników. Żal, że zamiast ich wytęić, zniszczyć, dopuszczono ich do udziału w życiu spoleczeństwa, że zgodzono się na kompromisy, które oni - co byto do przewidzenia - wykorzystali na swoja korzyść, bo niby 
na czyja mieli wykorzystać? Że okazali się w tym wykorzystaniu solidarni (między soba). Żal, że oni potrafili wykorzystać chwilę, nie my (Boniecki 2014, s. 193).

W komentarzu „Alergikom na uspokojenie” (TP 2014/8) ks. A. Boniecki wypowiedział się stanowczo w sprawie wzburzenia opinii publicznej informacją o dotacji Ministerstwa Kultury i Dziedzictwa Narodowego na muzeum Jana Pawła II i kardynała Stefana Wyszyńskiego. Autor realistycznie zauważył, że irytacja wyrażona m.in. w mediach może być rozumiana jako przejaw alergii na obecność Kościoła w życiu publicznym. W tekście bardzo dobrze widoczna jest gradacja argumentów wspierających ideę muzeum i wyraźne rozdzielenie tej budowy od Świątyni Opatrzności Bożej. Omawiając echa medialne sprawy, Autor zacytował fragmenty artykułów z łamów m.in. Polityki, rzeczowo „rozbrajając” oburzone głowy.

Teksty ks. A. Bonieckiego często przetwarzane są w formę książek. Niezwykłe jest zapotrzebowanie na zrównoważone opinie, wolne od afektacji a skonstruowane na wiedzy, doświadczeniu, mądrości życiowej. Można wymienić inne tytuły książek ks. A. Bonieckiego, np. „Notes rzymski” (t. 1 1988, t. 2 1989), „Vademecum generała czyli czego nie robić i co robić, kiedy władza wpadnie ci w ręce” (1999), „Kościół w świecie zmieniającej się kultury” (2002), „Zrozumieć papieża: rozmowy o encyklikach” (2003), „Abonent chwilowo nieosiagalny” (2015), ,Powroty z bezdroży. Notatki na marginesach Biblii” (2017).

\section{Wiarygodny publicysta i madry czlowiek}

Wybory komentarzy, powyżej omówione, stanowią bardzo dobry przykład tego, jak ks. A. Boniecki rozumie edukacyjną funkcję mediów i odpowiedzialność za słowo. Są realizacją przykazań M. Środy, ze szczególnym uwzględnieniem nakazu niejątrzenia i niejudzenia oraz tolerancji, gotowości słuchania innych. Komentarze te przyciagają także mistrzostwem formy, jasnym i klarownym wykładaniem racji, logika, czytelnym przesłaniem (dlatego tak często cytowałam ostatnie akapity, będące rodzajem puenty; zwykle jednak zawierające zachętę do wymiany poglądów; otwarte na kontytuowanie dyskusji).

Sprawy, którym Redaktor Senior poświęca swoją uwagę, na pewno są istotne i ciagłe, ,zanurzone w trwaniu”. Autor zwykle dba o przedstawienie tha wydarzeń, objaśnienie kontekstów, faktów i udziału osób drugiego planu. Nie skazuje czytelnika na domyślanie się aluzji, analogii i sugestii, ale wyraźnie określa przestrzeń swoich skojarzeń. To bardzo ważna cecha dziennikarstwa poważnego, umożliwiająca zbudowanie więzi pomiędzy autorami i odbiorcami komunikatów. Zaufanie do ks. A. Bonieckiego jako publicysty narastało dzięki Jego spokojowi, odwadze wypowiadania niepopularnych prawd (vide, zarzuty wobec Tygodnika Powszechnego), ujmującej skromności (Ksiądz zawsze zaznacza, że mówi tylko w swoim imieniu, źle się czuje ustawiany na piedestale), wiedzy. W wielu miejscach zaprzecza Norwidowskiej kategorii „strachu prawdy”. Pisze o słaboś- 
ciach ludzi, ale i narodu, o winach Kościoła instytucji i księży. Na łamach pisma katolickiego przeciwstawia naukową narrację dogmatom Kościoła, zawsze dostrzegając dramatyzm decyzji ludzi, którzy samotni wobec wyboru, przyjmują rozwiązania sprzeczne z nauką Kościoła i wiara, ale jedyne możliwe. Na tym polega wielkość ks. A. Bonieckiego, że nie osądza, ale próbuje zrozumieć. W wielu kręgach Ksiądz jest dzisiaj wskazywany jako autorytet.

W dniach od 6 do 12 sierpnia 2017 roku w Szczebrzeszynie - po raz trzeci odbywał się Festiwal Języka Polskiego. Ks. Adam Boniecki był jednym z jego gości, obok Hanny Krall, Wiesława Myśliwskiego, Mai Komorowskiej, Andrzeja Seweryna. Po dwugodzinnym spotkaniu pod namiotem festiwalowym i wokół zebrało się ponad 600 osób, kolejne trzy godziny trwały rozmowy i podpisywanie książek. Odczuwało się autentyczną potrzebę słuchania i bycia razem dłużej.

Z inicjatywy Rodziny Leopolda Ungera, publicysty należącego do międzynarodowej elity dziennikarstwa poważnego, w 2013 roku, został uruchomiony program stypendialny i stażowy dla młodych dziennikarzy. W redakcjach: Polity$k i$, Le Soir, Gazety Wyborczej i biurze prasowym Forum Ekonomicznego w Krynicy (miejsce, z którym był związany L. Unger) uczą się oni etyki i warsztatu zawodowego. Ks. A. Boniecki, jako jeden z mentorów, zasiada w Kapitule Stypendium.

\section{Bibliografia}

Ankieta Tygodnika Powszechnego (2006a). Tygodnik Powszechny, nr 3 (2949), s. 8-9.

Ankieta Tygodnika Powszechnego (2006b). Tygodnik Powszechny, nr 4 (2950), s. 5.

Bachmann K. (2008). Pożytki ze wścibskiej prasy. Gazeta Wyborcza, 14-15 VI 2008, s. 27.

Boniecki A. (2005). Mody. Ks. Adam Boniecki, redaktor naczelny Tygodnika Powszechnego. Świat według naczelnych. Przekrój, nr 6 (3111), s. 16-17.

Boniecki A. (2006). Przykazania medialne. Tygodnik Powszechny, nr 2, s. 2.

Boniecki A. (2011). Lepiej palić fajkę niż czarownice... Kraków.

Boniecki A. (2014). Zakaz palenia. Kraków.

Dąbrowska M., Stempowski J. (2010). Listy 1954-1965, t. III. Warszawa.

Hofman I. (2012). Dziennikarstwo poważne - wartość w mediach na przykładzie Polski, Serious Journalism - The Value in the Media on the Polish Example. Communication Today, nr 3, s. 94-102.

Kapuściński R. (2002). We władzy mediów. Polityka, nr 13(2343), s. 13.

Kapuściński R. (2003). Autoportret reportera. Kraków.

Mucharski A. (2011). Ksiądz Adam Boniecki ma głos. W: ks. A. Boniecki. Lepiej palić fajkę niż czarownice (s. 5). Kraków.

Mucharski P. (2014). Ksiądz Adam Boniecki pisze co tydzień... W: ks. A. Boniecki. Zakaz palenia (s. 5). Kraków.

Pisarek W. (2006). Słownik terminologii medialnej. Kraków.

Poulet B. (2011). Śmierć gazet i przyszłość informacji. Wołowiec.

Środa M. (2005). Media à la Wassermann. Gazeta Wyborcza, 1-2 X, s. 18-19.

Środa M. (2008). Dziennikarskie grzechy główne. Gazeta Wyborcza, 4 III, s. 21.

Wojtak M. (2004). Gatunki prasowe. Lublin. 


\section{STRESZCZENIE}

Ksiądz Adam Boniecki jako Redaktor Senior Tygodnika Powszechnego wydał dwa zbiory komentarzy, znanych wcześniej z publikacji w tygodniku w latach 2008-2014. Są to: „Lepiej palić fajkę niż czarownice” (2011) i „Zakaz palenia” (2014). Komentarze te spełniają kryteria gatunkowe, zwłaszcza w wyraźnej ekspozycji poglądów Autora i gotowości do wysłuchania innej argumentacji lub interpretacji. Są też bardzo dobrym przykładem dziennikarstwa poważnego, które rozumiem jako rodzaj pisarstwa informacyjnego i publicystycznego na tematy istotne dla odbiorcy w pespektywie globalnej lub lokalnej, uwiarygodnionego autorytetem autora, cechującego się poszanowaniem relacji komunikacyjnych. W pierwszej części artykułu omawiam przebieg dyskusji środowiskowej na temat standardów dziennikarstwa, w tym stanowiska redaktorów naczelnych prasy opiniotwórczej. W drugiej części - przedstawiam analizę zawartości wybranych tekstów ks. A. Bonieckiego. Komentarze na łamach Tygodnika Powszechnego były poświęcone głównie kwestiom społecznym, w których nauka Kościoła ma decydujący wpływ na zachowania ludzi (np. sakramenty dla rozwiedzionych, aborcja, in vitro), jak również tematyce religijnej (uroczystości i obyczaje związane z rokiem liturgicznym, upolitycznienie kazań, malejąca liczba powołań).

Slowa kluczowe: publicystyka, Tygodnik Powszechny, dziennikarstwo poważne, opinia publiczna 